\title{
The Root Causes of Conflicts in the Horn of Africa
}

\author{
Muhabie Mekonnen Mengistu \\ Department of Cooperatives, Hawassa University, Hawassa, Ethiopia
}

Email address:

muhabiemekonnen@yahoo.com

\section{To cite this article:}

Muhabie Mekonnen Mengistu. The Root Causes of Conflicts in the Horn of Africa. American Journal of Applied Psychology. Vol. 4, No. 2, 2015, pp. 28-34. doi: 10.11648/j.ajap.20150402.12

\begin{abstract}
The Horn of Africa (HOA) has been mentioned as one of the most disputed regions of the globe. It has been experienced with a number of armed conflicts, ethno-linguistic disputes, religious radicalism where in it catches the attention of most developed nations including US for their strategic interest over the region. Accordingly, this paper attempted to identify and critically analyze the due reasons for an escalated war and instability throughout the region. By collecting secondary data from different reliable and verifiable sources, the data were analyzed using a combination of interpretivism and constructivism to guide the qualitative method of research. Hence, the output of the research depicted that the HOA is challenged by diversified intra-state and inter-state conflicts among the neighboring countries owing to economic, social, political and historical grounds. Most of them were rooting to boarder and territorial conflicts and ethnic and religious polarization. There are also resource centered disputes especially on the Red Sea, Indian Ocean and River Nile (the start of Ethiopia to construct The Great Renaissance Dam brings tension and anxiety among the three competing countries i.e. Ethiopia, Sudan and Egypt). Though it is less sever, an armed cattle-raiding conflict in the frontier border lines of some of the states of the horn make them in trouble occasionally. Footed on identity conflicts, clan or religious based political parties struggle for power by provoking the peaceful society to get in to violence for their personal interests at the expense of the community. Even after they took power these parties will be either dictatorial or against good governance which drives multifaceted dispute with in a society. However, it is possible to peacefully resolve or prevent these issues including anticipating possible conflicts to early warn them, strategic intervention and necessary action, if required, by the sub-regional, regional and international organizations. It is pertinent to use cultural conflict resolution methods by involving ethnic figureheads and religious leaders for discussion and to hamper conflict escalations.
\end{abstract}

Keywords: Causes, Conflicts, Escalation, Ethnic polarization, Horn of Africa, Radicalism

\section{Introduction}

\subsection{Background of the Study}

Conflict is undesirable. In its violent form, it claims the lives of many people, destroys property, and diverts human as well as financial resources away from development. (Alexander Attilio, 2002). The Horn region is one of the most conflict-ravaged areas on the African continent. It is a region well known in African politics of being a volatile, hostile and poor place due to numerous conflicts, wars, and colorizations The populations of the region have endured many inter-state and intra-state armed conflicts. Although interconnected, the region's conflicts occur at several levels, including direct inter-state wars and armed conflicts; intra-state civil wars and conflicts; and inter-communal conflicts (Kidane M., 2011).

The fact that the Horn of Africa is central to the politics of the USA, Europe and the Arab world has gained worldwide recognition due to the frequent incidents of war in the region. The solution for the conflicts in the area should be sought in the context of the history, political system, religious affiliations and economic relations of the Horn countries to the rest of the world. Recent changes in the political order of the world may have also changed the influence of the East on the Horn countries. This has been demonstrated in the direction western countries are taking on matters concerning the Horn countries especially after the end of the cold war. This, however, does not mean that the old ties between the Horn countries and the East has been broken. The tie between them has only been loosened and it can be tightened in times of emergency. This factor can intensify conflicts between neighbouring countries of the Horn (Shemelis Gizaw, 2003). 
Violent conflict is more the norm than the exception in the Horn of Africa. Conflicts are waged at various levels: state, regional, and local. Conflict involves various actors: governments, nationalist groups, religious groups, and community or identity groups with significant backing from external forces. It is a common for conflicts in the sub-region to promptly acquire a sub-regional dimension, thus transcending national borders by attracting kinsmen from across the border. The result is often a flow of refugees, who destabilize economic and trade relations between neighboring states, and pose a security threat to the sub-region.

Therefore, this study focuses on empirical explanations and critical analysis of the deep roots of conflicts in the Horn of Africa.

\subsection{Objectives of the Study}

The main objective of the study is to identify the root causes of conflicts in the horn of Africa.

\subsection{Study Methodology}

Due to time and financial constraints, the study was entirely based on secondary data. And the collected data were analyzed using a combination of interpretivism and constructivism to guide the qualitative method of research (Dessler, 1999:123-125).

\section{Theoretical Framework}

\subsection{What is Conflict?}

Conflict is an active disagreement between people with opposing opinions or principles. It is present when two or more parties perceive that their interests are incompatible, express hostile attitudes, or take pursue their interests through actions that damage the other parties. These parties may be individuals, small or large groups, and countries.

Interests can diverge in many ways:

- Over resources-territory, money, energy sources, food - and how they should be distributed.

- Over power, how control and participation in political decision-making are allocated.

- Over identity, concerning the cultural, social and political communities to which people feel tied.

- Over status, whether people believe they are treated with respect and dignity and whether their traditions and social position are respected.

- Over values, particularly those embodied in systems of government, religion, or ideology.

Conflict on the other hand can be defined as the contradictions inherent in power relations and which manifest themselves in individual and group interactions with one another and with nature in the pursuit of limited resources or opportunities. Conflict is the motor of transformation and is either positive or negative. It can be creatively transformed to ensure equity, progress and harmony; or destructively transformed to engender acute insecurity.

\subsection{Causes of Conflicts}

As it has been depicted by Meala; 2011, the literature available regarding the causes of conflict often showed how leading scholars influence the perception and, subsequently, shape policies. They attempt to explain factors leading to conflicts, such as Kaplan1 (1994), who perceived the African continent as wild and backward. Huntington (1993) explained conflicts due to the interaction of different cultures leading to clashes, radicalisation and fundamentalism. Moreover, Chabal and Daloz (1999) can be under the same umbrella by viewing Africa of the Post-Cold War as the 'way it works'. These explanations of conflicts tend to generalise and stereotype conflicts as irrational. Henceforth, it is important to enhance the research by looking at the question of rationality. Thus, Collier and Hoeffler (1998) explained this notion, which will be useful in the analytical explanation of the return to conflict. In other words, they see the rationale driven by economic grievances creating new types of war, as argued by Mary Kaldor's 'new wars' (2006). Although, this notion is broader than former scholars mentioned, it remains a narrow explanation of the causes of violence and conflict only from an economic perspective neglecting other factors i.e. political power, self-determination and external actors' implications. Additionally, conflicts due to geographical situation are increasingly significant in literature; indeed, Clare (2001) explained this phenomenon to be influenced by vital interests and contested resources zones. Territories and boundaries, especially in Africa, is matter of debate and thus, the literature on this subject is important to assess.

Salim (1999) on his hand classifies conflicts in Africa as follows: boundary and territorial conflicts, civil wars and internal conflicts having international repercussions, succession conflicts in territories decolonised, political and ideological conflicts, others including those related to transhumance and irredentism. Similarly, Collier and Binswanger (1999) classify conflicts into (a) loot seekers and (b) justice-seekers, classification which is based more on value judgment rather than analytical criteria. Nevertheless, both Salim and Binswanger use what they consider to be the objectives of the rebel groups as criterion for classifying conflicts. Others, as I will do below, classify conflicts on the bases of the actors involved in a conflict. Still others are concerned only with conflicts in which the state is a party to the conflict.

In general, most writers tend to think of conflicts in Africa as being political conflicts such as wars between states, armed rebellion against states (ranging from small-scale low intensity conflicts to large-scale civil war), armed secessionist rebellion (also of various scales), and coup d'etat Indeed, most African conflicts which are reported and which draw international attention, are those which fit the above description.

\subsection{Natures of Conflicts}

Conflicting interests can be pursued without violence or coercion: not all conflicts are violent. Conflicts handled 
peacefully and non-coercively can be positive events. Societies can progress when parties' changing needs are identified and accommodated, as happens when minorities are recognized and better served.

Peaceful conflicts are handled according to regulated mechanisms to pursue competing interests. Various factors regulate conflict: national constitutions and laws, family and clan structures, court systems, Robert's Rules of Order, the Law of the Sea, religious codes, habits of decorum, debate and discourse, among other mechanisms. These can be informal and tacit-social mores and customs. They can also be highly formal and institutionalized, as in a nation's written statutes. Elections are a classic way that conflicts can be addressed peacefully. Recent research shows that violent conflicts-irredention, rebellion, inter-communal violence, civil war-account for less than one percent of potential conflicts in regions such as sub-Saharan Africa and the former republics of the Soviet Union. Peaceful conflict resolution mechanisms can be traditional or modern, local, national, or international. Such mechanisms operate effectively in the regions and communities around the world called "zones of peace," generally keeping these areas' social and international conflicts from becoming destructive and violent.

Violent conflict: Conflicts can become violent when parties go beyond seeking to attain their goals peacefully, and try to dominate or destroy the opposing parties' ability to pursue their own interests.

With so much violence around the world, we might assume that violent conflict and coercion are the natural order of things: human beings are inherently aggressive, and wars and violent conflicts are inevitable. Yet violence does not always occur, even when interests differ: violence is not inevitable. Violence is contingent upon the presence or absence of certain conditions.

Different dimensions distinguish violent conflicts:

- The main substantive issues in contention or interests at stake-natural resource competition, government control, territorial control, governing ideologies.

- The parties involved-ethnic, religious or regional communities, states, political factions.

- The types of force or coercion used-nuclear war, conventional war, terrorism, coups, repression, genocide, gross human rights violations, ethnic cleansing.

- The geographic scope or arena for killing and destruction-international conflicts, inter-communal conflicts, state-sponsored terrorism.

Different levels of conflict vary in the degree of cooperation or hostility. Some conflicts may be handled amicably without coercion or violence. Others rise to high levels of confrontation or involve repression and sustained physical violence.

These levels of interaction in conflicts can be arranged along a continuum from cooperative to hostile relationsfrom total harmony of interests to sustained all-out war. This continuum shows that there is overlap between peace and war. The overlap is reflected in graduated terms such as "hot war," "cold war," "co-existence," "rivalry," "detente," "alliance," "special relationship," "confederation," and so on.

\subsection{Emergence and Cessation of Conflicts}

Conflicts change over time; hostilities emerge, grow and abate.

\subsubsection{Dynamics of Escalation}

Dynamic and interactive processes in individual and collective behavior explain whether hostile attitudes and behavior escalate or not.

Escalation may be vertical-hostile behavior becomes more intense - or horizontal-hostile behavior of the same intensity spreads over a larger area. Escalation can take both forms. Escalation can be caused by the parties themselves or by actions that third parties take. Spiraling conflicts are fueled by a set of social-psychological phenomena within each party's collective mind and behavior. People get more committed to a struggle as they become more involved. A sense of urgency takes over; time pressures to make decisions narrow options to little more than existing courses of action. The psychological investment that conflict requires shapes each side's perceptions of the other: one's own cause is seen as just, the other side's as evil.

Leaders may become more committed to their positions once they are announced publicly: it becomes harder to back down. Commitment to fight increases; once conflict is being waged, specialists in using force gain influence over the government's or organization's leadership and policies. Escalation proceeds: harmed parties feel justified in striking back, and vice versa. Coercion and violence discourage communication between the parties, limiting opportunities for addressing issues through compromise.

\subsubsection{Early Warning}

Truly preventive action requires early intervention to avoid being caught by surprise when conflicts erupt. Policy-makers must know how to recognize signs of impending conflict in order to make decisions based on informed analysis and marshall the resources required to head off incipient violence. Anticipating possible conflicts is not a matter of precisely predicting specific events and their timing since this level of exactitude is not possible. Instead, early warning means judging the probability that certain events will lead to violence or other crises. This requires reliable information on a range of possible common events-border crises, disintegrating regimes, civil wars, genocide, human rights abuses, refugee flows and estimating where these are most likely to emerge.

Threats to security and national order emerge subtly out of social, political, economic and cultural, international, national and local conditions and events. These indicators are as diverse as price fluctuations, demonstrations, government policies, social movements, political infighting, leaders' attitudes, and arms flows. At the same time, change, tension and political turmoil can be positive as well as negative in transitions between economic and political systems. 
Monitoring and information-gathering must reach deeply into a country's social fabric and grassroots politics to identify possible sources of conflict.

\section{Data Analysis and Interpretation}

\subsection{Profile and Dynamics of the Region}

In these days, the Horn of Africa consists of seven countries, including Ethiopia, Eritrea, Djibouti, Kenya, Somalia, Sudan and Uganda, which are members of IGAD. Southern Sudan, become independent on 9 July 2011, joins the region in the recent times. Moreover, if Somaliland, which has declared its independence from the rest of Somalia, achieves international recognition as an independent state, the number of countries in the region will increase to nine. However, it should be noted that the fragmentation of Sudan into north and south is likely to add to the region's instability than it was before.

In spite of its significant improvement in human development and economic growth over the last two decade, the Horn of Africa is still one of the most insecure regions in the world and ranks low on global indicators of human security, rule of law and good governance.

Though interconnected, the region's conflicts happens in different forms, including wars between states, armed rebellion against states (ranging from small-scale low intensity conflicts to large-scale civil war), armed secessionist rebellion (also of various scales), and coup d'etat However, the degree of conflict and tensions varies from country to country: dealing with conflict in the Greater Horn ranges from stopping active wars to protecting and strengthening peace so that violence is not triggered. In areas currently in violent conflict, the main challenge is to contain the conflict, alleviate suffering, and if possible, reduce the violence. Where conflicts have abated but tensions remain high, principal tasks are reconstruction, social reconciliation and healing so that social and economic progress can be made and future conflicts avoided. This means resolving tensions over ethnic relations, human rights, and political representation to ensure that further violence does not destroy or thwart larger achievements.

Even though the region lasts full scale inter-state conflicts (the Ethio-Eritrean war ended in 2000); ongoing inter-clan fighting (in Somalia till today); Cross-border fighting (between Sudan and South Sudan in 2012); Terrorism (emergence of a more radical Islamist insurgency group, al Shebab in Somalia) and other boarder issues put in to effect between Uganda and Kenya, between Kenya and Sudan over the Elemi triangle and those between Ethiopia and Sudan, most parts of the regions has remained under poverty line and feel unsafe over the past years.

A range of structural violence, such as economic disparity or gender inequality and intra state conflicts among different communities are realities faced by people throughout region. The structural conflict and violence of the regions is found in different depth and beneath from local to national and regional levels.

\subsection{Causes of Conflict in the Region}

The horn of Africa is the home of different ethnicities, religions and cultures. However, the peoples of the region are interconnected in one or other ways. But the question here is why it is a conflicting zone than the rest of Africa mind in it as having relative comparable historical evolvements starting from the early ages. The following major factors contributed much for the socio-economic unrest of the region. While some causes are purely internal and portray specific country dynamics, others have a significant regional and international dimension.

\subsubsection{Economic Causes/Competition over and Mismanagement of Economic Resources/}

\section{(i) Significant Strategic Importance}

Many of the horn conflicts can be linked directly to contests for the control of resources such as the Red Sea, Indian Ocean, oil, agriculture and grazing lands and water resources like River Nile. This rivalry can be stretched from local to international levels.

The Red Sea and the Indian Ocean are the most important sea routes which are shared by at least four countries in the Horn of Africa (Eritrea, Djibouti, Somalia and Sudan) are, at this time, getting back sizeable strategic importance in international maritime trade among the Middle Eastern, Asian countries and the Russians to open new markets in Africa. Likewise, to be advantageous from an ample oil extraction and to flood their electronic products towards Africa, the Far East Asian countries and the rest of the world choose these water routes. To this end, interest conflicts will appear between opponent parties. There are also some nations which take this conflicting region as a potential area for their arm sale. Surprisingly, beyond acting as arm sellers of the region, they are also usually protagonists of most of the violent incidences of the area.

Even though the country is in political chaos and disturbances inside its political opponents, the South Sudan have unexploited oil resources which are considered to the nucleus of conflict with its counterpart i.e. the Northern Sudan. Ethiopia nowadays, being the water tower of East and North Africa, is progressing by utilizing its water resources (start to construct The Great Renaissance Dam) nevertheless its international rivers like the so called Abay are the source of tension and conflict among Egypt and Sudan which are historically the foremost users of the river. Supposed to be its internal problems be resolved, Ethiopia has significant agricultural potential wherein the Arab Emirates and the Asian countries are investing more on the country. This could be the source of conflict between the countries peoples and the government as the people considers some investments like flower productions are degrading the land and make it impossible to reutilize it again. Furthermore, though the government consider it as the source of foreign currency and employment but the peoples still assume as exploitation of 
the potential resources and modern land grapping system without the at most benefit of the nation.

Within or with that of the neighboring country, it is usual to get a conflict of pastoralist over the use of natural resources such as water and grazing land for their cattle. However, these peoples are also clashing over because of cultural practices of heroism, cross-border and local livestock raiding and a need of socio-cultural fairness. Depletion of pastoral grazing areas cause one of the bordering countries pastoral to migrate to the other which lead in to conflict between the newly arriving group and the main settles there. And even due to the encroachment of the pasture land by agriculturalists, there are repeated incidences of conflicts of farmer-herders.

\section{(ii) Resource is Everything}

$\mathrm{Be}$ it in scarcity and unwise use of it can led in to extreme war and violent conflicts. The map of the conflict of the horn is further complicated and tensioned by factors like chronic poverty, unemployment (especially youth), unfair distribution of resources and extreme contestation over decentralized resources. These are the means for the stiff competition amongst the political elites even in a stable political environment for the purpose of rent seeking. This is, nowadays; a headache for almost all countries of the horn.

\subsubsection{Historical Legacies}

\section{(i) Colonization}

Just after the independence of the horn countries they started to search their country demarcations, however; the only option to have the line of demarcation for the newly formed states was accepting the colonizers set but which was not fully accepted by every countries of the region or it was invisible. To this end, neighboring countries got in to armed conflicts or wars. The 1961, $1964-67,1977-1978$ and 2006- 2009 Ethio-Somalia war and the 1998-2000 EthioEriteria war are some but major manifestations of this colonial-boarder settings. The colonial sentiments in the mindsets of the peoples of the region are also mentioned as one factor of conflict.

\section{(ii) Having a Unique Conflict Dynamics}

Historically, the region's conflict dynamics was quite distinct from the patterns found among its sub-Saharan and North African neighbors. The region's states had a long history of supporting insurgents in neighboring states in order to weaken what they consider to be oppositional regimes. Moreover, all nations of the region had a felt need of enlarging their territory by grapping from the neighboring country rather than by deliberate round table discussions. A few instances of this action has been reflected by Eritrea by supporting various Ethiopian insurgency groups against the Ethiopian government and the Ethiopian regime in turn react by supporting Eritrean opposition groups, such as the Eritrean Democratic Alliance and The Red Sea Afar Democratic Organisation (RSADO).

\section{(iii) Dictatorial and Oppressive Regimes}

In the former times even today, it is common to find undemocratic and oppressive regimes which were or are supported and sustained by super nations for the sake of their interests across the region. The derge military junta of Ethiopia repeatedly supported by Russia and Cuba, The government of Idi Amin from Uganda and Siad Barre of Somalia are some but bold instances of oppressive ruling systems of the horn.

\section{(iv) The Cold War}

During this period, internal conflicts of the HOA were both aggravated and contained by the super powers on both sides. The influence of the super powers was very strong and invisible state party. Countries of the horn were boiled by supporting either of the blocks where in the ruling party and the opposition parties will have different alienations towards these two ideologies. To this end, the super powers will assist, especially militarily and armament for these groups. The military junta of Ethiopia (Derge) had strong attachment with the Soviet Union. And there was a large amount of flow of arms towards Ethiopia. On the other hand, TPLF (the rebellious group at that time) was highly supported by USA. Finally, due to the confrontations of these groups, there was mass destruction in the country.

\subsubsection{Social and Cultural Causes}

\section{(i) Extreme Religious Politics}

As witnessed by Sudan and Somalia, the region is threatened by Islamic religion fundamentalists who may escort in to rivalry between Sunni and Shi'ite Islams athwart the horn. The international community as well as the states of the region also tensioned by these emerging radical religious groups.

\section{(ii) Ethnic Polarity}

As it is known by its multi-ethnic groups, Horn of Africa (HOA) is also a home of racial divergence groups. Some of them thought that they were excluded by the former governmental systems and they started to hatred other ethnicities which are assumed to have a strong tie with the previous systems. In Ethiopia, though the reality is different, the oromo and some other ethnic groups consider as Amhara peoples were the at most beneficiaries of the then governments. This is one of the major factors that direct the intrastate conflicts in the country. The political elites of the country, in the present days, use this as a fertile ground for manipulation of ethnic and regional sentiments. It has a spillover effect of cultural detachment and the search for identity by developing a perception of they are not belongs to some social groups. Due to the legacy of colonialism, several ethnic groups like Somalia- Moquadisho with that of Ethiopian Somalia and Kenyan Somalia who claims homogeneity are today straddling across international boundaries between neighboring states.

As far as identity (religion and ethnicity) conflict of the HOA concerns, the "We" and "Those", "They" and "Us" and 
"Ours" and "Others" mentality deconstructed that had led to the loss of togetherness, empathy and sympathy among the peoples. This opened the way for political entrepreneurs and ethnic activists to fire the tensed groups to go to ethnic conflicts.

\subsubsection{Political Causes}

\section{(i) Power Struggle}

Most of politicians of the region are not visionaries rather they struggle to seize state power seemingly for the purpose of rent seeking and in order to redress grievances that leads to the weakening of the state.

\section{(ii) Poor Governance and Transparency}

Most of the countries of the HOA are known for their centralized states which contribute for the acceleration of instabilities which at the end directs to their fragmentation and failure. The ruling parties ignore power sharing and try to preach the people as they are democratic ones. HOA is thirsted of peaceful election. Most often the successors came in to power either by force or external support rather than by the full consent of the people. The political crises of the area are explained by civil wars, the restraining of civil liberties and the abuse of human rights.

\section{Conclusion and Recommendation}

\subsection{Conclusion}

Tracing back to the early times and coming forth to the present days and potentially in the future, the HOA is the most volatile, fragile and exposed for numerous inter and intra state disputes. This could include socio-political, economical and historical origins though there is no one size for all recipe.

Religious extremism and ethnic polarity are the deep rooted foundations of the escalated violence among the states of HOA. The Somalia civil war can be identified as a typical instance in this context. The terrorist network such as AlShabab, have driven instability and religious extremism in the region. These groups have also encouraged coiled with other equipped groups, such as the Ogaden National Liberation Front in Ethiopia's Ogaden region. Ethnicity makes these countries susceptible to disputes mainly as a result of the "we-versus them" situation that it brings into the already tense reservations among the different ethnic groups.

Besides to improper management of resources, the horn's considerable strategic importance to control of the resources such as the Red Sea, Indian Ocean, oil, agriculture and grazing lands and water resources like River Nile is one of the due reasons for the continuous dispute among the states of the confined territory. History also contributes for the prevailing conflicts in a way that colonial sentiments and colonial border demarcation impose countries to clash over. Moreover, the region's states had a long history of supporting insurgents in neighboring states in order to weaken what they consider to be oppositional regimes.
It is impractical to find sound economic policies but to the contrary it is common to observe an dictatorial leadership where majority of the countries give less democratic space and opposition political parties were targeted and dwindled. Gagging the media and practicing politics of exclusion are also some of the conflict-escorting grounds of the area.

\subsection{Recommendation}

As depicted in the conclusion above, it is possible to utter that the countries of the Horn of Africa remain, even today, suffering a lot of violent conflicts which is caused by sociopolitical and economic factors. Hence, it is pertinent to put some feasible recommendations. Accordingly, the researcher suggested the following reasonable recommendations which possibly will put out the region from its current prevailing disputes.

- The actors of conflicts of the HOA should give priority and work on conflict prevention actions and stretching a system of anticipating possible conflicts to early warn them. An early warning response system is needed to identify dispute risks at an early stage and take action to prevent the escalation of conflicts into violent forms.

- The International, Regional and Sub-regional organizations like IGAD, AU and UN should scrutinize the root causes of conflicts of the region and they have to strategically intervene and take action if necessary. This could be done by:

- Strengthening the Secretariat of the IGAD to address regional issues such as nomadic- pastoral conflicts.

- Building regional conflict management capacity by AU and this could alleviate the destructive effects of international influences i.e. states which has a particular self-interest around the region.

$\circ$ Putting holistic effort (UN, AU and IGAD) to the facilitation of negotiation for peaceful resolution of existing conflicts and the effective implementation of peace agreements.

- The states themselves should work on common political policies specifically on their foreign policies of each other to bring at least normative peace among the society.

- Building strong law and order institutions which responds proportionally to any kind of conflicts over the region.

- Promoting the cultural conflict resolution mechanisms in which inculcating religious and ethnic leaders as they know their problems therein they can easily convince to bring up peoples under their clan or religion for discussion and it is also a way that blocks conflicts not to be escalated.

- Clear demarcation of borders in between countries of the horn. A few years ago, The Ethiopian-Kenyan border harmonisation committee has started addressing the cross-border dimensions of the conflicts. Likewise, there should be clear cut boarder lines among countries of the HOA so as to settle repeated disputes among themselves. 


\section{Appendix A: Glossary}

Conflict Escalation: can be vertical wherein hostile behavior becomes more intense or horizontal wherein hostile behavior of the same intensity spreads over a larger area.

Conflict is a relationship between two or more parties (individuals or groups) who have, or think they have incompatible goals. Depending on the goals and behavior conflict was further categorised as no conflict, latent conflict (below the surface), open conflict (deep rooted) and surface conflict (shallow).

Conflict management: aims to limit and avoid future violence by promoting positive behavioral changes in the parties involved.

Conflict prevention aims to prevent the outbreak of violent conflict

Conflict resolution: aims to address the causes of conflict and seeks to build new and lasting relationships between hostile groups.

Early Warning: early intervention to avoid being caught by surprise when conflicts erupt.

Ethnic Activists: peoples who use ethnic approaches such as "WE" and "THEY" to create a division and to persuade their own and to dislike others.

Ethnic Polarity: a situation where highly or sharply extreme ethnic group appears in a society.

Political Entrepreneurs: people who look for private interest and they use segmentation at times of election contest

Religious Radicalism: a condition of polarizing religion for manipulating it for meeting personal interests. Eg. Alshahbab

Violence consists of actions, words, attitudes, structures or systems that cause physical, psychological, social or environmental damage and/or prevent people from reaching their human potential

\section{References}

[1] Attilio A., (2003). Geo-Political Explanations of Conflict in the Horn of Africa. Ethiopia: OSSREA Ethiopia Chapter

[2] Bujra A. (2002). African Conflicts: Their Causes and Their Political and Social Environment. Development Policy Management Forum, Ethiopia, Addis Ababa

[3] Cliffe L. (1999). Regional dimensions of conflict in the Horn of Africa. JSTOR:Third World Quarterly, Vol 20 (1), pp 89111.

[4] Collier, P. \& Hoeffler, A. (1998). On Economic Causes of Civil War. Oxford Economic Papers 1998. 50. Pp. 563-573.
[5] Dessler, D. (1999). Review: Constructivism within a Positivist Social Science. Review of International Studies. 25 (1). Jan 1999. Pp. 123-137.

[6] Huntington, S. (1993). The Clash of Civilisations? Foreign Affairs. 1993. 72 (3). Pp.22-49.

[7] Insoll T.(2003). The Archeology of Islam in Sub-Saharan Africa, UK: Cambridge University Press

[8] Kidane Mengisteab (2011). Critical Factors in the Horn of Africa's Raging Conflicts. UK: Lightning Source UK Ltd.

[9] Lotze, W. Et al. (2008). Peace building Coordination in African Countries: Transitioning from Conflict: Case Studies of the Democratic Republic of the Congo, Liberia and South Sudan. Occasional Paper Series, ACCORD. 2008.3 (1). Pp. 171 .

[10] Meala Tesfamichael (2011). The Causes of Return to Conflict and the Geographical Dynamics in the Horn of Africa: The Eritrean- Ethiopian Boarder Conflict. MA Dissertation in Politics, SAOS, University of London.

[11] Michael D. McGinnis 1999. Conflict Dynamics in a ThreeLevel Game:Local, National, and International Conflict in the Horn of Africa. Department of Political Science and Workshop in Political Theory and Policy Analysis Indiana University, Pp 5-17.

[12] Ncube M. and Jones B, (2013). Drivers and Dynamics of Fragility in Africa. African Development Bank, Africa Economic Brief, 4(5).

[13] Nuur M. S. Nena T. (2006) Comparative Research On Cross Border Pastoral Conflicts In The East African Region-Case Studies From Ethiopia, Kenya, Sudan And Uganda. Workshop Report,UNECA, Ethiopia, Addis Ababa

[14] Shemelis Gizaw (2003). Conflict in the Horn: Prevention and Resolution. Ethiopia: OSSREA Ethiopia Chapter

[15] Tadesse Berhe and Yonas Adaye, (2007). Afar: The impact of local conflict on regional stability Journal of Researching local conflicts and regional security, the Institute for Security Studies

[16] Williams P. (2011). Horn of Africa: Webs of Conflict \& Pathways to Peace. USA: George Washington University, Woodrow Wilson International Center for Scholars

[17] Yasin Mohammed Yasin (2010). Regional Dynamics of Interethnic Conflicts in the Horn of Africa: An Analysis of the Afar-Somali Conflict in Ethiopia and Djibouti. University of Hamburg, Germany

[18] Yohannes Gebre Michael, Kassaye Hadgu and Zerihun Ambaye (2005). Addressing Pastoralist Conflict in Ethiopia: The case of the Kuraz and Hamer sub-districts of South Omo zone. Africa Peace Forum, Ethiopian Pastoralist Research and Development Association, Interafrica Group, Saferworld 